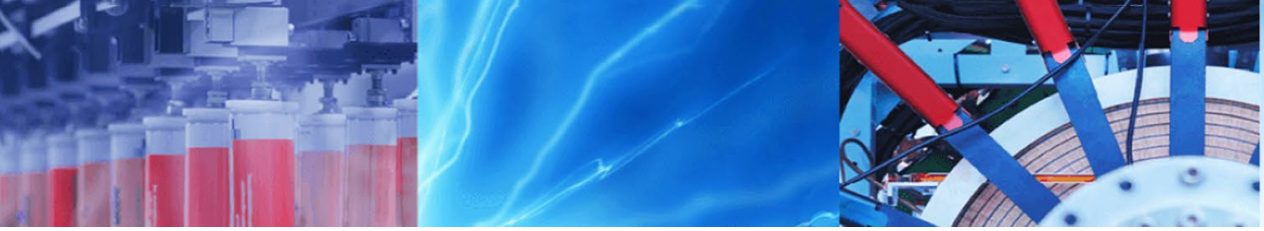

Research Article

\title{
Purification and optimization of pink pigment produced by newly isolated bacterial strain Enterobacter sp. PWN1
}

\author{
Kasturi Poddar $^{1} \cdot$ Bhagyashree Padhan $^{1} \cdot$ Debapriya Sarkar $^{1} \cdot$ Angana Sarkar $^{1}$
}

Received: 2 October 2020 / Accepted: 4 January 2021 / Published online: 11 January 2021

(C) The Author(s) 2021 OPEN

\begin{abstract}
Pigment-producing bacteria were isolated from kitchen wastewaters of the National Institute of Technology, Rourkela. A pink non-virulent bacterial strain PWN1 was selected based on the India Ink Broth and Coomassie Brilliant Blue (R-250) dye assay. According to morphological and biochemical characterization, the strain PWN1 was a Gram-negative, rodshaped, motile, non-coliform bacterium and could utilize only glucose and adonitol as sole carbon source. The pigment was found to be a growth-associated product, and the pigment production was accelerated after $40 \mathrm{~h}$ of bacterial culture. Further, $16 \mathrm{~S}$ rRNA gene-based molecular identification showed its similarity with Enterobacter sp. The pigments were extracted by the solvent extraction method using chloroform and ethanol (3:1). The extracted pigments were then purified through thin-layer chromatography and column chromatography. To maximize pigment production, the culture condition was optimized for maximum biomass production using statistical software Design Expert v13. A quadratic model was structured describing the process efficiently and it suggested a moderate temperature, $\mathrm{pH}$, and a high inoculum concentration which generated biomass of $3.81 \pm 0.02 \mathrm{~g} / \mathrm{L}$. At optimized condition, $1 \mathrm{~L}$ of cell culture produced $3.77 \mathrm{~g}$ of biomass which produced a crude pigment of $0.234 \mathrm{~g}$ after solvent extraction and $0.131 \mathrm{~g}$ after column chromatography, implying a yield of $6.2 \%$ for crude pigment and $3.47 \%$ for purified pigment from biomass. The yield of the obtained pigment was high enough to draw interest for industrial production, although the application of the pigment is considerable for further study.
\end{abstract}

Keywords Bacterial pigment · Solvent extraction · Chromatography · Optimization

\section{Introduction}

Pigments are colorful secondary metabolites produced by bacteria for survival advantage. Bacteria thriving in harsh and extreme environments suffer from stress and damage to bacterial cells which force them to come up with a mechanism for cell adaptation; pigment production is one such mechanism [1]. For instance, bacteria in the cold region such as the Antarctic suffer from both low temperatures as well as constant UV exposure, therefore bacteria tend to produce pigments like carotenoids which protect against cellular damage due to UV exposure, allowing bacteria to survive through the environment [2]. It has also been shown that colored bacteria have a better chance of survival when exposed to ozone and peroxide than non-pigment-producing bacteria [3]. Pigment production in bacteria not only provides protection but also serves many other functions such as resistance to other

Supplementary information The online version contains supplementary material available at (https://doi.org/10.1007/s42452-021-04146 $-\mathrm{x})$.

$\triangle$ Angana Sarkar, sarkara@nitrkl.ac.in; sarkar.angana@gmail.com; Kasturi Poddar, kasturi.p93@gmail.com; Bhagyashree Padhan, bhagyashreepadhan96@gmail.com; Debapriya Sarkar, deb.apn@gmail.com | Department of Biotechnology and Medical Engineering, National Institute of Technology Rourkela, Odisha 769008, India. 
microbes and phagocytosis and light-harvesting molecules for photosynthesis. It also serves as a basis for the taxonomic classification of bacteria.

Bacteria producing pigments can be found in a wide variety of habitats ranging from oceans to rhizospheric soil [4], Antarctic regions [2] to desert areas [5] from tree bark to insect gut [6]. The bacterial strains responsible for the production of pigments are as vast and diverse as their niche. Some pigment-producing bacterial strains are listed in Table 1. The most common bacterial genus responsible for the production of pigments includes Streptomyces spp., Staphylococcus spp., Arthrobacter spp., Pseudomonas spp., and Chryseobacterium spp. producing diverse pigments including carotenoids, flexirubin, prodigiosin, pyocyanin, violacein, staphyloxanthin, melanin, flavonoids, etc. $[7,8]$.

Pigments obtained from bacteria find applications in various industries such as textiles, food, pharmaceuticals, cosmetics, and others. In the textile industry, pigments like prodigiosin (red) and pyocyanin (blue) have been used to dye fabrics that curbed the growth of microorganisms like Staphylococcus aureus and Escherichia coli $[18,16]$. Similarly, violacein pigment obtained from Janthinobacterium lividum can be used for dyeing fabric. The antimicrobial, antioxidant, antileishmanial, anticancer, antiviral properties of bacterial pigments prove their potential in pharmaceutical applications. Carotenoids produced by bacteria of Arthrobacter sp. and Staphylococcus sp. have shown anticancer properties against cancer cell lines and thus can be used as anticancer drugs. Wound healing activities are also observed in certain bacterial pigments such as pyranone $[6,10,15]$. Apart from industrial and pharmaceutical use, bacterial pigments can also be used for application in solar cells as dye sensitizers [2].

Bacteria are preferred over other sources for pigment production because of several advantages. A shorter life cycle and compatibility with environmental changes make bacterial source ideal for pigment extraction. Apart from this, bacterial cultures are easy to maintain and scalable for industrial use and can be grown using cheap, easily available, renewable sources that reduce the cost of production. Besides being natural, bacterial pigments also possess various properties such as antibacterial, antimicrobial, antioxidant, antileishmanial, anticancer, and antitubercular activities which increases their potential use in industries such as textile, food, cosmetics, and pharmaceuticals. To replace the hazardous synthetic pigment industry and meet the market demand, different colors and shades of bacterial pigments need to be discovered. Kitchen wastewater is a nutrient-rich microbial reservoir with previous reports suggesting it as a source of much resourceful bacterial communities. In that context, the present study was focused on isolation, purification, and optimization of bacterial pigment from kitchen wastewater.

\section{Materials and methods}

\subsection{Screening and isolation of pigment-producing bacteria}

Kitchen wastewater samples from the National Institute of Technology Rourkela, India $\left(22.2514^{\circ} \mathrm{N}, 84.9115^{\circ} \mathrm{E}\right)$ were collected in clean, sterile containers and the temperature of the sample at the time of collection was measured to be $\sim 30 \pm 0.4^{\circ} \mathrm{C}$ with a pH of about $7.5 \pm 0.2$. The water sample was serially diluted at $10^{-7}$ dilution rates, using autoclaved distilled water, and $250 \mu \mathrm{L}$ of the diluted samples were spread on sterile R-2A (M1687, Himedia, India) agar plates with media composition for $1000 \mathrm{ml}$ : Casein acid hydrolysate: $0.5 \mathrm{~g}$, Yeast extract: $0.5 \mathrm{~g}$, Protease peptone: $0.5 \mathrm{~g}$, Dextrose: $0.5 \mathrm{~g}$, Starch, soluble: $0.5 \mathrm{~g}$, Dipotassium phosphate: $0.3 \mathrm{~g}$, Magnesium sulfate: $0.024 \mathrm{~g}$, Sodium
Table 1 Application of different pigments obtained from bacteria

\begin{tabular}{lllll}
\hline No. & Bacteria & Pigment & Application & References \\
\hline 1. & Hymenobacterium sp. & Carotenoids & Solar cells & {$[2]$} \\
& Chryseobacterium sp. & & & \\
2. & Serratia sp. & Red pigment & Antimicrobial & {$[9]$} \\
3. & Arthrobacter sp. & Carotenoids & Anticancer activity & {$[10]$} \\
4. & Streptomyces sp. & Undecylprodigiosin & Pharmaceutical activities & {$[11]$} \\
5. & Streptomyces bellus & Unknown & Antioxidant activity & {$[12]$} \\
6. & Cellulophaga fucicola & Carotenoid & Antioxidant activity & {$[13]$} \\
7. & Serratia marcescens & Prodigiosin & Textile dye & {$[14]$} \\
8. & Vibrio sp. & Pyranone & Wound healing and anti- & {$[15]$} \\
& & & bacterial activity & \\
9. & Pseudomonas aeruginosa & Pyocyanin & Textile dye & {$[16]$} \\
10. & Staphylococcus gallinarum & Staphyloxanthin & Anticancer activity & {$[6]$} \\
11. & Janthinobacterium lividum & Violacein & Fabric dye & {$[17]$} \\
\hline
\end{tabular}


pyruvate: $0.3 \mathrm{~g}$, Agar powder: $1.5 \%$. The plates were then incubated at $30^{\circ} \mathrm{C}$ for 3 days. Pure cultures of the pigmentproducing bacterial strains were obtained by subsequent plating and culturing of the colonies from culture media to fresh media.

\subsection{Virulence assay}

The pigment-producing bacterial colonies were screened based on their inherited virulence. The cultures were primarily examined by filtered India Ink (CAMLI-SOL 100, Kokuyo Camlin Ltd.) using $0.22 \mu \mathrm{m}$ syringe driven filters (SF-126, Himedia, India) in R-2A broth [19]. R-2A broth of $5 \mathrm{ml}$ containing $1 \%$ of the filtered ink was inoculated with $250 \mu \mathrm{l}$ of freshly grown bacterial cultures and incubated at $30^{\circ} \mathrm{C}$ for $48 \mathrm{~h}$. The absorption of the ink from the culture broth by the bacterial cells was measured by evaluating the transmittance of the cell-free culture broth using UV 3200 UV-Vis Spectrophotometer (Lab India, India) at $600 \mathrm{~nm}$ wavelength. The pathogenic trait of the bacterial strains was further confirmed by streaking the fresh bacterial cultures on $0.01 \%$ Coomassie Brilliant Blue (CBB) R-250 (MB153, Himedia, India) containing R-2A agar plates incubated at $30^{\circ} \mathrm{C}$ for a period of $36 \mathrm{~h}$ [20].

\subsection{Characterization of pigment-producing strain}

\subsubsection{Biochemical characterization}

The bacteria were characterized by Gram staining using Gram Staining Kit (K001) from Himedia, India [21]. The spore-forming nature of the isolates was identified by the standard procedure using malachite green for $10 \mathrm{~min}$ on the pre-heat-fixed smear that stains up the endospores produced by the bacteria on exposure to stress [22]. The motility of the bacteria was identified by the standard hanging drop method, using fresh cultures on concavity slides and their visualization under 1000X microscopic magnification [23]. The microstructure was examined under Quanta 600 FEG Environmental Scanning Electron Microscope (ESEM) (FEl, Japan) to identify the cellular dimensions. Fresh cultured cells were smeared on carbon tape to observe under $15 \mathrm{kV}$ power and $300 \mathrm{~Pa}$ pressure at a magnification of 50000X [24]. The coliform nature of the isolated strain was determined using the IMViC Test Kit (Himedia, India) which included indole, methyl red (MR), Voges-Proskauer (VP), and citrate utilization tests. The different forms of carbohydrate compounds utilized by the strains were separately examined, which included glucose, adonitol, arabinose, lactose, sorbitol, mannitol, rhamnose, and sucrose $[25,26]$.

\subsubsection{Molecular identification and phylogenetic analysis}

The molecular identification of the bacterial isolate was done by partial sequencing of the 16S rRNA gene. For this purpose, the genomic DNA of the bacterial strains was isolated following the phenol-chloroform-isoamyl ( $\mathrm{PCl})$ alcohol extraction method using a standard protocol. The 16S rRNA gene from the genomic DNA was extracted out and amplified using hot-start PCR (Veriti 96-Well Thermal Cycler, Applied Biosystems, Thermo Fischer Scientific, Singapore). For this purpose, 27F forward and 1492R reverse universal degenerative primers were used [27]. The initial hot stage was conducted by maintaining $94{ }^{\circ} \mathrm{C}$ for $5 \mathrm{~min}$ which is followed by 35 cycles comprising a denaturation stage of $94^{\circ} \mathrm{C}$ for $15 \mathrm{~s}$, an annealing stage of $52^{\circ} \mathrm{C}$ for $50 \mathrm{~s}$, and an elongation stage of $72^{\circ} \mathrm{C}$ for $90 \mathrm{~s}$. At the end of the 35 cycles, a concluding extension step was incorporated for $10 \mathrm{~min}$. The PCR amplified DNA was further purified using Gel Extraction Kit (Genetix Biotech Asia Pvt Ltd., India) before outsourcing for the sequencing from Eurofins Sequencing Services (Eurofins Genomics India Pvt Ltd., Bangalore, India). The BioEdit tool (v7.0.5) was used to remove the noise and low signals from the obtained sequencing results. The homology analysis was conducted to find out related strains using the BLASTN tool of the National Centre for Biotechnology Information (NCBI) database. A phylogenetic tree was composed considering the neighbor-joining method using the sequences obtained from the BLAST analysis after a multiple alignment analysis using the CLUSTALW algorithm in MEGA-7 [28]. The identified sequence of the non-virulent pigmentproducing strain was submitted to GenBank with Accession number MK943548.

\subsection{Production and extraction of pigment}

The non-pathogenic pigment-producing PWN1 strain was cultured in sterile $100 \mathrm{ml} \mathrm{R}-2 \mathrm{~A}$ broth at $30^{\circ} \mathrm{C}$ for 7 days with $140 \mathrm{rpm}$ rotational shaking. The extraction of the intracellular pigments from the broth was carried out using a modified solvent extraction procedure [29]. To determine the best solvent for the extraction of intracellular pigment, different polar solvents viz. ethanol, methanol, and acetone, and non-polar solvents viz. diethyl ether, hexane, and chloroform were examined. For each solvent initially, $15 \mathrm{ml}$ of 7 days old culture was centrifuged at $7800 \mathrm{rpm}$ at $30^{\circ} \mathrm{C}$ for $15 \mathrm{~min}$ to obtain the cell pellet followed by dissolving the pellets in $5 \mathrm{ml}$ of the solvent. The cells in the solvent were then subjected to ultrasonication treatment digital ultrasonic cleaner (LCMU-2, Labman Scientific Instruments, India) till the cells turn white. The mixture was then centrifuged at $4{ }^{\circ} \mathrm{C}, 7800 \mathrm{rpm}$ for $15 \mathrm{~min}$ to extract the pigment from the cell debris. 


\subsection{Purification of pigment}

The methanol extracted pigment was eluted using different solvent mixtures on pre-coated thin-layer chromatography (TLC) plates from TLC Silica gel $60 \mathrm{~F}_{254^{\prime}}$ (Merck, India). Different solvent mixtures with varying proportions like methanol:acetone:water (4:4:2); ethanol:water:chloroform (4:2:4) and (4:4:2); hexane:acetone (3:2) and (4:1); petroleum ether:ethyl acetate (9:1) and (1:9);chloroform:ethanol (2:1) and (3:1) were examined as the mobile phase to separate the different compounds of the pigment $[29,30]$. The sample was loaded onto the plate at a height of $1 \mathrm{~cm}$ from the bottom, and the plate was then placed in the different developing chambers containing the solvent ratios. After the solvent font reached the marked line, the TLC plates were visualized under UV light. The retention factor $\left(R_{f}\right)$ was calculated from the distances traveled by the solvent and the pigment compound following Eq. 1 [31].

Retention factor $\left(R_{\mathrm{f}}\right)=\frac{\text { Distance traveled by compound }}{\text { Distance traveled by the solvent }}$

The pigment was further purified by column chromatography to separate the different fractions using Silica Gel G (GRM7480, Himedia, India) suspended in hexane. The elution of the target band was obtained by the best performing elution mixture obtained from the TLC analysis. As the elution proceeded, readily separable bands of the pigment were collected in separate test tubes from the outlet. TLC was performed for each elutes produced to check the homogeneity and similarity of the compound purified out from the column. The purified compound was then collected in a round bottle and dried in a rotary evaporator to form a powder.

\subsection{Optimization of cell growth}

The pigment produced by isolated bacterial strain was found to be intracellular, hence to maximize the pigment production the biomass production had to be maximized. To achieve this, the biomass production was optimized considering the 3 most important process parameters which included, temperature coded as $\mathrm{A}, \mathrm{pH}$ coded as $\mathrm{B}$, and inoculum percentage coded as $C$. As changing the $\mathrm{pH}$ at minute level is very difficult to achieve and hard to maintain, the $\mathrm{pH}$ was considered as hard-to-change (HTC) factor. The range of the temperature for the optimization study was considered $25-40{ }^{\circ} \mathrm{C}, \mathrm{pH} 5-9$, and inoculum percentage $1.5-3.5 \%$. A starter culture with cell concentration $0.28 \mathrm{~g} / \mathrm{L}(\mathrm{OD}=0.52)$ was used as inoculum culture. Design Expert trial version (v13) was used to construct the central composite design (CCD) which suggested 23 runs. The runs were performed randomly in triplicates for 3 days. After analyzing the response, a model equation was suggested by the software. The accuracy of the suggested model was statistically examined by evaluating the different parameters which included, SSR (regression sum of squares), SSE (error sum of squares), and SST (corrected sum of squares). Moreover, the significance of the model was statistically evaluated by Fisher's $F$-test, and the fit quality was determined by the coefficient of determination $\left(R^{2}\right)$. The model showing a minimum $95 \%$ level of confidence was considered significant. Response surface methodology (RSM) analysis was performed to construct the contour graph representing the interactions between the different process parameters and used to determine the optimum region to get the maximum biomass yield. Based on this analysis, the software suggested a probable solution for the highest biomass yield as a particular temperature, $\mathrm{pH}$, and inoculum concentration. The practical biomass yield in the suggested physiological condition was determined and analyzed to establish the acceptance and reliability of the suggested process model.

\subsection{Kinetic study and pigment yield calculation}

Kinetic study on cell growth and pigment production of bacterial strain Enterobacter sp. PWN1 was conducted in $3 \mathrm{~L}$ of R-2A broth at optimized conditions [32]. Hundred $\mathrm{ml}$ of samples were collected at certain time intervals, and cell mass was obtained by centrifugation. From the collected cell mass, the crude pigment was extracted and weighed. The cell mass and pigment recovered data were converted to $\mathrm{g} / \mathrm{L}$ and plot against time (h). The specific growth rate and specific pigment production rate were calculated. Moreover, a separate $1 \mathrm{~L}$ of culture was maintained for 3 days at the optimized condition to calculate pigment yield from biomass.

\subsection{Statistical analysis}

All the experiments were conducted in triplicates, and the obtained results were represented as the mean value. Different individual experiments were considered significant showing a relative standard deviation of less than $0.5 \%$.

\section{Results and discussion}

\subsection{Isolation and characterization of pigment-producing bacteria}

From the spread plate, 2 different pigment-producing bacterial colonies (PWN1 and PWp1) were identified and subsequently streaked repeatedly to obtain a pure culture 
Fig. 1 Isolated pigmentproducing strain. a Pigmented colonies produced by isolated bacterial strain Enterobacter sp. PWN1 on R-2A agar plate. b Pathogenic strain PWp1 producing blue-colored colonies. c Non-pathogenic strain PWN1 producing white-colored colonies. d Environmental Scanning Electron Microscopic (ESEM) image of PWN1 with cell length in a range of $1-1.3 \mu \mathrm{m}$
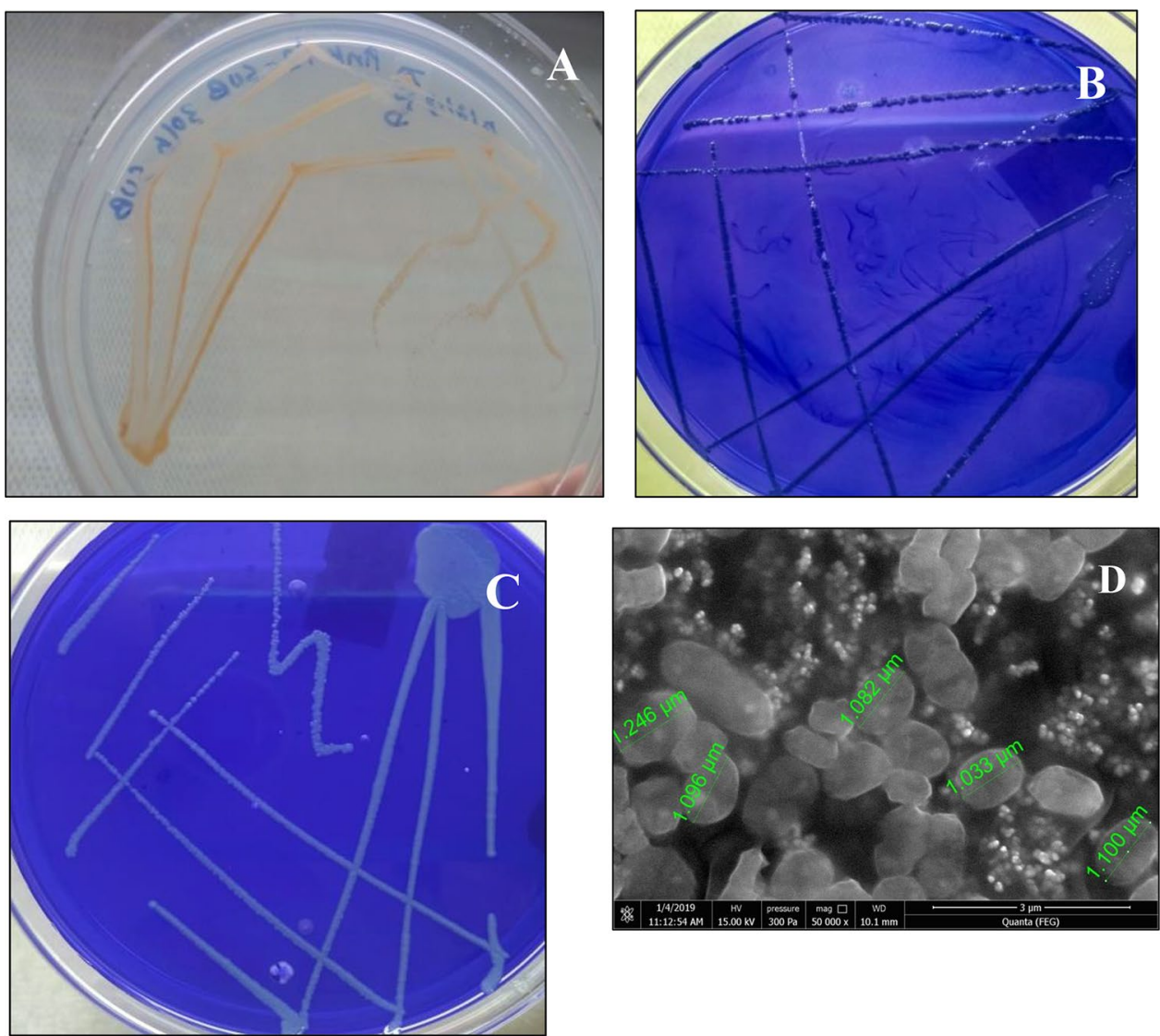

of the strains (Fig. 1a). The result from the India Ink experiment showed a higher transmittance value of the cell-free culture broth for strain PWp1 and also exhibited blue colonies in the CBB agar plate which indicated the presence of an A-layer (protective protein layer outside the cell wall). The presence of this A-layer is a trait of a virulent bacterial strain [19]. Hence, the strain PWp1 was suspected with inherent pathogenicity (Fig. 1b). On the other hand, the cell-free culture broth of the strain PWN1 showed lower transmittance value in the India Ink test and also produced white colonies in CBB signifying the absence of any such protein layer outside the cell wall (Fig. 1C) [20]. Therefore, the PWN1 strain was considered to be non-pathogenic and safe for further use. Giving importance to the laboratory safety issue, further experiments were carried out only with the PWN1 strain. The bacterial morphological study revealed that the strain PWN1 was Gram-negative, ovalshaped, and non-endospore forming. The strain was found motile when observed under 1000X microscopic magnification during the hanging drop analysis. Environmental scanning electron microscope analysis of strain PWN1 showed that the isolated cells were short oval-shaped with an average cell length of $1.11 \mu \mathrm{m}$ which was similar to the cellular morphology of Enterobacter sp. where the length is measured in the range of $0.8-2 \mu \mathrm{m}$ (Fig. 1d)
[33]. The culture broth of the bacterial strain showed no color change in the indole production test indicating its inability to produce indole from tryptophan. A similar negative result was obtained in the methyl red test as the color of the culture broth remained yellowish-orange. It signifies that the bacterial strain was not producing acid. In the Voges-Proskauer test, the color of the culture broth remained colorless indicating no production of acetoin by glucose fermentation. The strain was also found unable to utilize citrate as a carbohydrate source since no color change was observed in the citrate utilization assay. Moreover, the bacterial strain exhibited a narrow preference for carbohydrates as it was observed that it could survive only in the presence of glucose and adonitol, whereas other carbohydrate sources which included arabinose, lactose, sorbitol, mannitol, rhamnose, and sucrose-containing media was incapable to support the bacterial growth.

The obtained partial 16S rRNA sequence of the strain PWN1 was initially analyzed in BLAST. The report suggested its high similarity with Enterobacter sp. 90-A1 (KC920583), Pantoea agglomerans FL85 (KY818994), Enterobacter cancerogenus UW11 (KP209255), and other bacteria from Enterobacteriaceae family. But phylogenetic analysis using MEGA7 suggested that the PWN1 strain was situated in the same clad with Enterobacter sp. 
90-A1 (KC920583), and Enterobacter cloacae AMST Aie29 (JQ312033) with a bootstrap value of 98 and 64\%, respectively (Fig. 2). Another residence of the clad was Serratia marcescens strain AS-1 (AB270613). Among these bacteria, E. cloacae and $S$. marcescens already have reports of yellow and pink pigment production, respectively [34].

\subsection{Extraction and purification of bacterial pigment}

The solvent extraction process revealed methanol to be the best extraction solvent for the intercellular pigment as, after the cell lysis, the cell debris turns completely white and the solvent acquired the pink color of the pigment. On the other hand, other tried solvents like ethanol, diethyl ether, chloroform, hexane, and acetone did not acquire the color of the pigment and the cell debris remained pink indicating the lower extraction efficiency of the solvents (Fig. 3a). Moreover, the extracted pigment was found able to resolve best with the solvent mixture of chloroform:ethanol=3:1 in the thin-layer chromatography experiment. Comparative representation of resolving efficiency of other tried solvent mixtures has been presented in Table 2. The chloroform:ethanol mixture was able to resolve the extracted pigment in 4 separate bands based on the polarity of the compound present in the crude pigment. The most polar particle present in the crude pigment moved slowest with ethanol, while non-polar components of the crude pigment moved fast with chloroform in the TLC plate. The intermediate bands were formed based on their polarity. The second band which was showing the brightest presence of the color was slightly polar and was considered to be the purified pigment (Fig. 3b).
Fig. 2 Phylogenetic analysis of strain Enterobacter sp. PWN1 using neighbor-joining method

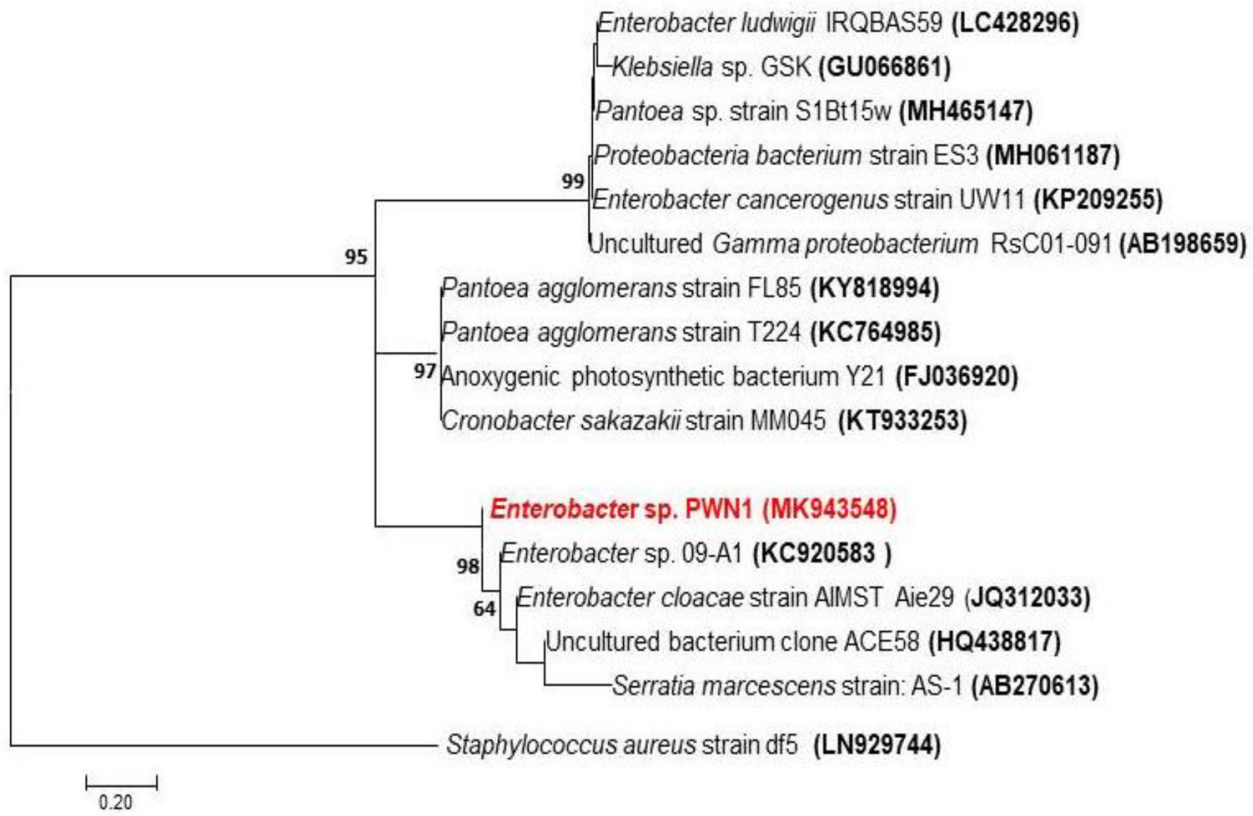

Fig. 3 Pigment extraction and purification. a Separation of pigment-producing cells from culture broth through centrifugation. b Thin-layer chromatographic separation of the different compounds in the pigment. The retention factor $\left(R_{\mathrm{f}}\right)$ value of the target compound was calculated as 0.6 . C Column chromatographic separation of the target pigment compound using chloroform and ethanol in the solvent phase, d Pigment compound obtained after purification
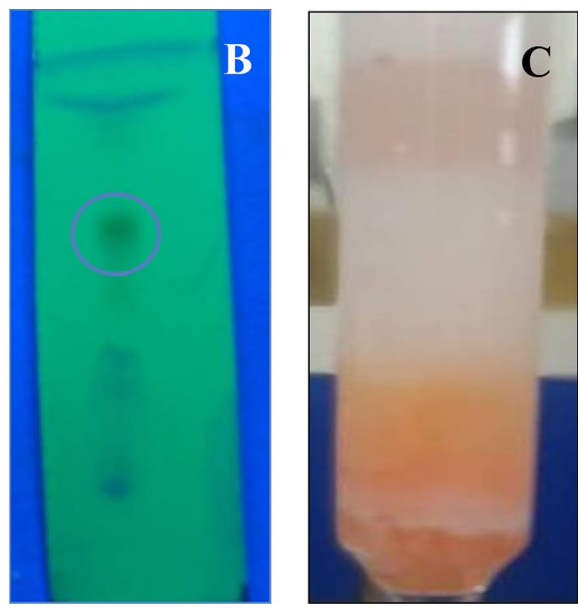

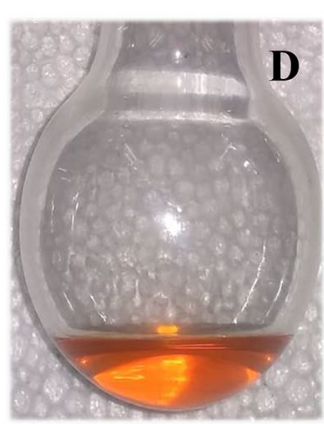


Table 2 Response of the pigment to different solvents in TLC

\begin{tabular}{llll}
\hline No. & Solvent & Ratio of solvents & Response \\
\hline 1. & Methanol: Acetone: Water & $4: 4: 2$ & - \\
2. & Ethanol: Water: Chloroform & $4: 4: 2$ & + \\
& & $4: 2: 4$ & + \\
3. & Hexane:Acetone & $3: 2$ & - \\
& & $4: 1$ & - \\
4. & Petroleum ether: Ethylacetate & $9: 1$ & - \\
& & $1: 9$ & - \\
5. & Ethanol: Chloroform & $1: 1$ & + \\
& & $1: 2$ & ++ \\
& & $1: 3$ & ++ \\
\hline
\end{tabular}

The $R_{f}$ value of the targeted band was calculated as 0.66 . From the result obtained in the TLC plate, column chromatography was conducted, and the first eluted band was discarded. Elutes from the second ring, a total of 17 different fractions were collected and each was tested in TLC for the presence of a single targeted band with retention factor 0.66 (Fig. 3c). All the purified pigment fractions giving positive results in TLC were collected in a round bottom flask (Fig. 3d). The purified pigment was dried in a vacuum evaporator and collected in powder form. A similar kind of intracellular pink-colored bacterial pigment, Prodigiosin was reported from Serratia marcescens using methanol as the extraction solvent. This pigment was also reported with anticancer and antibacterial activity $[35,36]$.

\subsection{Biomass production optimization}

To optimize the process parameters intending to maximize the biomass yield, 23 random runs were performed, and the obtained response (biomass concentration) is listed in Table 3. Based on the responses, the software suggested a quadratic model representing the process to be best suited for the representation of the process of biomass production shown as coded Eq. 2.
Table 3 Run table for biomass optimization of PWN1. The coded values for the factors have been mentioned in brackets

\begin{tabular}{|c|c|c|c|c|}
\hline Run & $\begin{array}{l}\text { Factor } 1 \\
\text { A: Temperature } \\
\left({ }^{\circ} \mathrm{C}\right)\end{array}$ & $\begin{array}{l}\text { Factor } 2 \\
\text { B: pH }\end{array}$ & $\begin{array}{l}\text { Factor } 3 \\
\text { C: Inoculum } \\
(\%)\end{array}$ & $\begin{array}{l}\text { Response } 1 \\
\text { Biomass } \\
\text { concentration } \\
(\mathrm{g} / \mathrm{L})\end{array}$ \\
\hline 1 & $25(-1)$ & $5(-1)$ & $2.34(-0.16)$ & 0.47 \\
\hline 2 & $33.7(+0.16)$ & $5(-1)$ & $3.5(+1)$ & 1.21 \\
\hline 3 & $40(+1)$ & $5(-1)$ & $1.5(-1)$ & 0.54 \\
\hline 4 & $40(+1)$ & $9(+1)$ & $1.5(-1)$ & 0.61 \\
\hline 5 & $31.825(-0.09)$ & $9(+1)$ & $2.6(+0.1)$ & 1.89 \\
\hline 6 & $25(-1)$ & $9(+1)$ & $3.5(+1)$ & 0.59 \\
\hline 7 & $25(-1)$ & $5(-1)$ & $3.5(+1)$ & 0.39 \\
\hline 8 & $31.3(-0.16)$ & $5(-1)$ & $1.5(-1)$ & 1.19 \\
\hline 9 & $40(+1)$ & $5(-1)$ & $2.64(+0.14)$ & 0.97 \\
\hline 10 & $25(-1)$ & $6.9(-0.05)$ & $3.5(+1)$ & 1.04 \\
\hline 11 & $40(+1)$ & $6.9(-0.05)$ & $3.5(+1)$ & 1.78 \\
\hline 12 & $25(-1)$ & $6.9(-0.05)$ & $1.5(-1)$ & 0.95 \\
\hline 13 & $32.5(0)$ & $7(0)$ & $2.5(0)$ & 3.89 \\
\hline 14 & $32.5(0)$ & $7(0)$ & $2.5(0)$ & 3.54 \\
\hline 15 & $25(-1)$ & $9(+1)$ & $1.5(-1)$ & 0.75 \\
\hline 16 & $33.1(+0.09)$ & $9(+1)$ & $2.41(-0.09)$ & 2.55 \\
\hline 17 & $40(+1)$ & $9(+1)$ & $3.5(+1)$ & 0.79 \\
\hline 18 & $32.5(0)$ & $7(0)$ & $2.5(0)$ & 3.64 \\
\hline 19 & $32.5(0)$ & $7(0)$ & $2.5(0)$ & 3.94 \\
\hline 20 & $32.5(0)$ & $7(0)$ & $2.5(0)$ & 2.98 \\
\hline 21 & $32.5(0)$ & $7(0)$ & $2.5(0)$ & 3.74 \\
\hline 22 & $32.5(0)$ & $7(0)$ & $2.5(0)$ & 3.64 \\
\hline 23 & $32.5(0)$ & $7(0)$ & $2.5(0)$ & 3.81 \\
\hline
\end{tabular}

non-significant (Table 4). On the other hand, the fit statistics of the model suggested that the difference between the predicted $R^{2}$ value (0.9576) and adjusted $R^{2}$ value (0.9780) was less than 0.2 indicating the colinearity of the predicted and actual values. Adequate precision, which is the ratio of signal to noise was found to be 33.5420 which is significantly high suggesting the model is very accurate to use as a navigation tool in the design space. The RSM

Obtained biomass concentration $=1.30+0.1639 A+0.1528 B-0.1172 A B+0.0951 A C-0.8525 A 2-0.7055 B 2-0.2627 C 2$

Where, $A$ represents the coded value of temperature, $B$ is the coded value for $\mathrm{pH}$, and $\mathrm{C}$ is the coded value of inoculum concentration. The ANOVA analysis of the equation suggested the model be significant as most of the model terms had a $P$ value less than 0.05 . The F-value of the whole model was found to be 140.55 which is significantly high indicating the statistical significance of the model. The F-value of the lack of fit of the model was significantly low. The ANOVA analysis also revealed that there was very little noise in the model as the lack of fit was found to be analysis revealed the interaction between the considered process parameters and had been represented as contour graphs (Fig. 4). However, the interaction between $\mathrm{pH}$ and inoculum concentration was found to be statistically nonsignificant and was not considered for the analysis.

The obtained model was solved for a solution to achieve maximum cell growth while setting the targeted temperature, $\mathrm{pH}$, and inoculum concentration in the given range. The software suggested a temperature of $33.18^{\circ} \mathrm{C}$, $\mathrm{pH} 7.20$, and inoculum concentration of $2.52 \%$ would be 
Table 4. ANOVA analysis for optimum biomass production by PWN1

\begin{tabular}{|c|c|c|c|c|c|c|}
\hline Source & Sum of Squares & $\mathrm{d} f$ & Mean square & $F$-value & $p$ value & \\
\hline Model & 13.88 & 7 & 1.98 & 140.55 & $<0.0001$ & Significant \\
\hline A-Temperature & 0.2876 & 1 & 0.2876 & 20.38 & 0.0004 & \\
\hline B-pH & 0.2754 & 1 & 0.2754 & 19.52 & 0.0005 & \\
\hline$A B$ & 0.1108 & 1 & 0.1108 & 7.85 & 0.0134 & \\
\hline AC & 0.0777 & 1 & 0.0777 & 5.50 & 0.0331 & \\
\hline$A^{2}$ & 2.21 & 1 & 2.21 & 156.51 & $<0.0001$ & \\
\hline$B^{2}$ & 2.21 & 1 & 2.21 & 156.72 & $<0.0001$ & \\
\hline$C^{2}$ & 0.2098 & 1 & 0.2098 & 14.87 & 0.0016 & \\
\hline Residual & 0.2116 & 15 & 0.0141 & & & \\
\hline Lack of Fit & 0.1573 & 8 & 0.0197 & 2.54 & 0.1188 & Not significant \\
\hline Pure Error & 0.0543 & 7 & 0.0078 & & & \\
\hline Cor Total & 14.09 & 22 & & & & \\
\hline
\end{tabular}
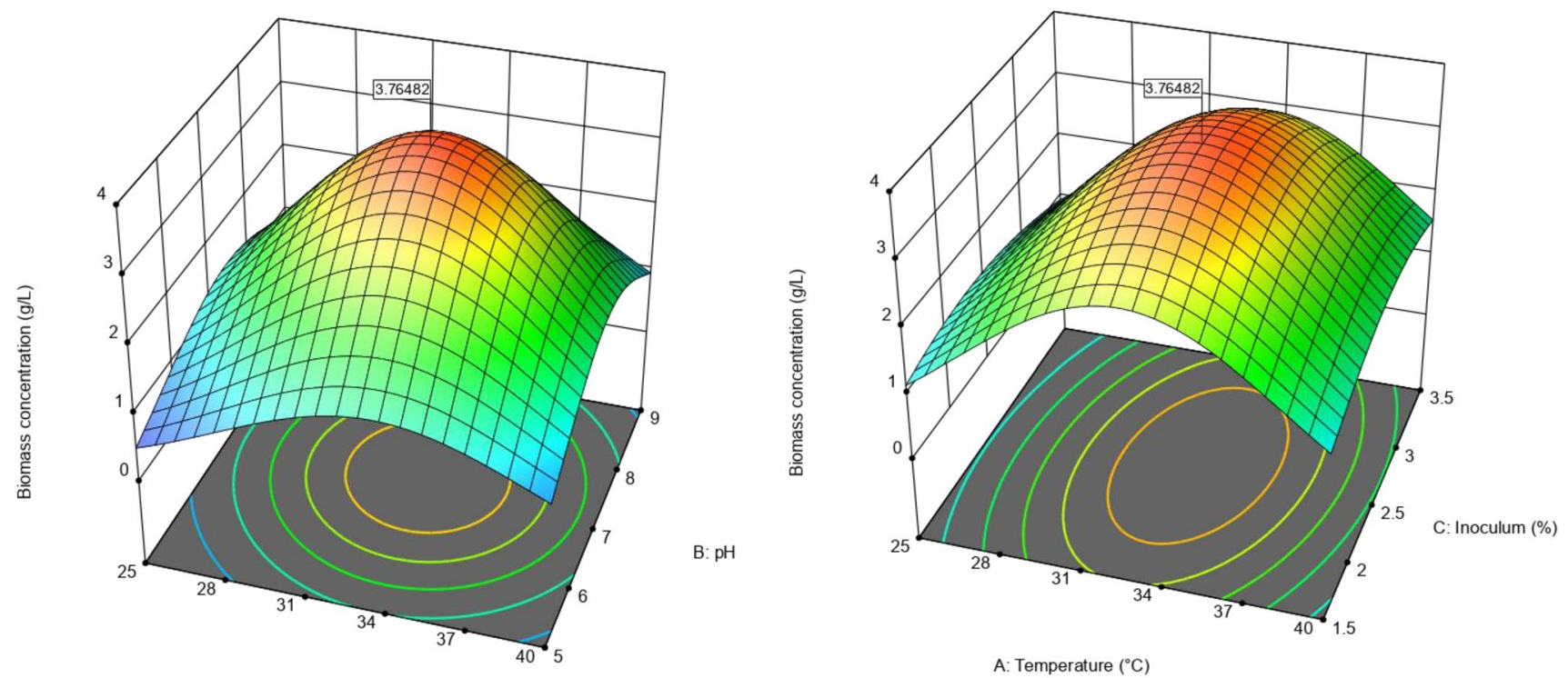

Fig. 4 Growth pattern of strain Enterobacter sp. PWN1 under effect of (a) Temperature and pH. b Temperature and Inoculum percentage

best to produce a biomass concentration of $3.77 \mathrm{~g} / \mathrm{L}$. The experimental run in these suggested culture conditions produced a biomass concentration of $3.81 \mathrm{~g} / \mathrm{L}$ which implied a $1.06 \%$ error in the prediction. This error may be caused by the small amount of noise of the model as well as the limitation of maintaining exact culture conditions. The optimized condition for the biomass production had been deduced as a temperature of $33.18^{\circ} \mathrm{C}, \mathrm{pH}$ of 7.20 , and $2.52 \%$ inoculum concentration after 3 days.

\subsection{Growth kinetics and pigment yield}

The growth kinetics curve between cell mass obtained versus time revealed that the log phase for the bacterial strain started after $15 \mathrm{~h}$ of culture and the same ends at around $55 \mathrm{~h}$ and the stationary phase lasts up to $27 \mathrm{~h}$ after which the biomass started to decline. From the production kinetic study, it was observed that the pigment production started after $25 \mathrm{~h}$ and the highest pigment was obtained at $72 \mathrm{~h}$. The nature of the curve indicates that the pigment production is growth associated, although the acceleration in the pigment production was slower than the cell growth (Fig. 5). From the kinetic analysis, the specific growth rate of the bacterial strain was found to be $0.069 / \mathrm{h}$ implying that the strain is very slow growing in nature. The cell mass productivity was also found to be very low as $0.043 \mathrm{~g} / \mathrm{h}$. The specific pigment production rate has been calculated as $1.18 \times 10^{-4} / \mathrm{h}$. The yield was obtained as $8.7 \mathrm{mg}$ of pigment from $1 \mathrm{~g}$ of biomass. 


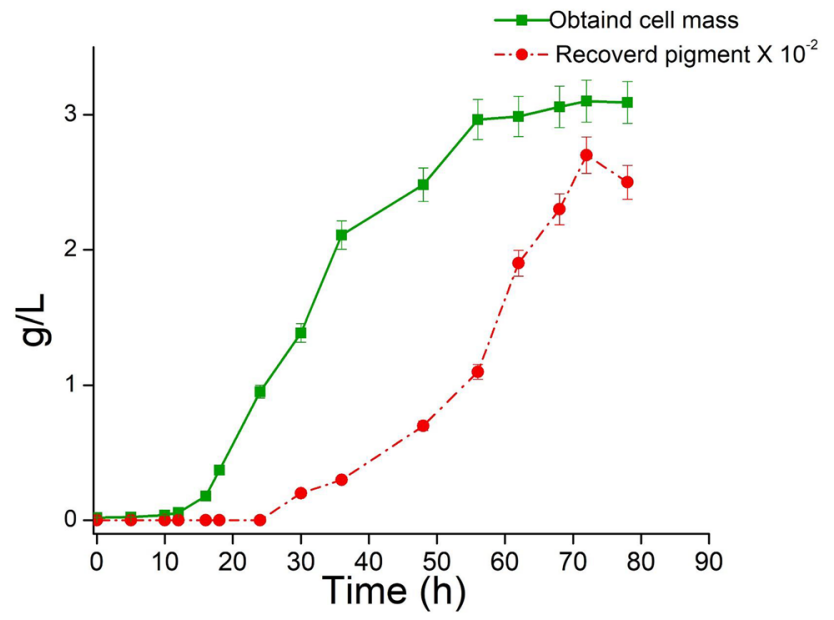

Fig. 5 Growth kinetics of Enterobacter sp. PWN1 and pigment production kinetics

During the yield analysis, $1 \mathrm{~L}$ culture produced a total of $3.77 \mathrm{~g}$ of biomass after 3 days of incubation at the optimized conditions. The solvent extraction process using methanol recovered a total of $0.234 \mathrm{~g}$ of crude pigment upon the vaporization of the methanol from the extraction mixture. This implied $6.2 \%$ of crude pigment recovery yield from biomass. After the TLC, a total of $0.131 \mathrm{~g}$ purified pigment was recovered with a recovery efficiency of $55.98 \%$ of purified pigment from crude pigment. The overall yield of purified pigment was deduced to be $3.47 \%$ of the biomass. The obtained yield is higher than many other reported intracellular bacterial pigments. For example, the yield of an intracellular yellow pigment collected from Vibrio owensii was reported to be $1.14 \%$ using butanol as an extraction solvent [37]. Another intracellular pigment, violacein was extracted from Duganella violaceinigra and Chromobacterium violacein showing a yield of $18.9 \mathrm{mg} / \mathrm{L}$ and $2.5 \mathrm{mg} / \mathrm{L}$, respectively, which were lower than the current study $[38,39]$. On the other hand, a carotenoid-like intracellular pigment was extracted from Arthrobacter sp. using solvent extraction showing a yield of $840 \mathrm{mg} / \mathrm{L}$ which is higher than the yield of the current study [10]. Another intracellular pigment, Prodigiosin from Serratia marcescens was also lower using freeze-thawing and homogenization [40]. The purification process of the current study achieving a significant yield was also useful as it is low energy involving, rapid, and cost-effective which makes the process of pigment extraction industrially feasible. Thus, the process of pink color intracellular bacterial pigment production stated in this current study is promising for industrial production and to fulfill the demand for the pink pigment in the market, although the application of the extracted pigment is a subject of further study and characterization of the isolated pigment.

\section{Conclusions}

A pink-colored intracellular bacterial pigment was extracted from bacterial strain PWN1 which was isolated from kitchen wastewater. The isolated strain was found to be non-pathogenic, Gram-negative, motile, and nonendospore forming in nature. The average cell size was observed to be $1.11 \mu \mathrm{m}$. The 16S rRNA gene sequencing and phylogenetic analysis established the relationship of the strain PWN1 with the Enterobacteriaceae family. The purification of the pigment was achieved by solvent extraction using methanol followed by column chromatography using elute solvent as 3:1 mixture of chloroform:ethanol. To maximize the biomass production, the culture condition was optimized considering temperature, $\mathrm{pH}$, and inoculum concentration as principal influencers. A quadratic model was established describing the process whose accuracy was evaluated with only $1.06 \%$ error. The kinetic analysis at the optimized condition revealed that after 3 days maximum pigment production was achieved. The final yield of purified pigment was found to be $3.47 \%$ from biomass which is relatively higher than most other intracellular bacterial pigments. The process of achieving a significant recovery of the purified pink pigment was cost-effective, sustainable, eco-friendly, and energy-efficient which makes it industrially feasible. However, more work should be done to identify and characterize the pigment to find out the industrial importance of it.

Acknowledgements The authors acknowledge the Biotechnology and Medical Engineering of the National Institute of Technology Rourkela, India for providing a suitable environment and technical facilities to conduct the research work.

Authors contribution The authors have contributed to the work and certify the originality of the work and that any similar material has not been submitted or published elsewhere.

Funding There have been no exclusive grants from any funding sources for the completion of this research.

Data Availability Any data would be made available on request.

\section{Compliance with ethical standards}

Conflict of interest The authors of this manuscript declare no conflict of interest for the submission of this manuscript to the journal "SN Applied Sciences".

Open Access This article is licensed under a Creative Commons Attribution 4.0 International License, which permits use, sharing, adaptation, distribution and reproduction in any medium or format, as long as you give appropriate credit to the original author(s) and the source, provide a link to the Creative Commons licence, and indicate if changes were made. The images or other third party material in this article are included in the article's Creative Commons licence, unless indicated otherwise in a credit line to the material. If material is not 
included in the article's Creative Commons licence and your intended use is not permitted by statutory regulation or exceeds the permitted use, you will need to obtain permission directly from the copyright holder. To view a copy of this licence, visit http://creativecommons .org/licenses/by/4.0/.

\section{References}

1. Vila E, Hornero-Méndez D, Azziz G, Lareo C, Saravia V (2019) Carotenoids from heterotrophic bacteria isolated from Fildes Peninsula King George Island, Antarctica. Biotechnol Rep. https ://doi.org/10.1016/j.btre.2019.e00306

2. Órdenes-Aenishanslins N, Anziani-Ostuni G, Vargas-Reyes M, Alarcón J, Tello A, Pérez-Donoso JM (2016) Pigments from UVresistant Antarctic bacteria as photosensitizers in dye sensitized solar cells. J Photochem Photobiol B Biol 162:707-714. https:// doi.org/10.1016/j.jphotobiol.2016.08.004

3. deOndarza J (2017) Ozone sensitivity and catalase activity in pigmented and non-pigmented strains of Serratia marcescens. Open Microbiol J 11:12-22. https://doi.org/10.2174/1874285801 711010012

4. Pawar RT, Mohandass C, Rajasabapathy R, Meena RM (2018) Molecular diversity of marine pigmented bacteria in the central Arabian Sea with special reference to antioxidant properties. Cah Biol Mar 59:409-420. https://doi.org/10.21411/ CBM.A.14870D31

5. Finger S, Godoy FA, Wittwer G, Aranda CP, Calderón R, Miranda CD (2018) Purification and characterization of indochrome type blue pigment produced by Pseudarthrobacter sp. $34 \mathrm{LCH} 1$ isolated from Atacama desert. J Ind Microbiol Biotechnol 46:101111. https://doi.org/10.1007/s10295-0188-2088-3

6. Barretto DA, Vootla SK (2018) In vitro anticancer activity of staphyloxanthin pigment extracted from Staphylococcus gallinarumKX912244, a gut microbe of Bombyxmori. Indian J Microbiol 58:146-158. https://doi.org/10.1007/s12088-018-0718-0

7. Park SA, Ahn S, Choi K (2020) Functional microbial pigments isolated from Chryseobacterium and Deinococcus species for biopaint application. Biotechnol Bioproc E 25:394-402. https://doi. org/10.1007/s12257-019-0372-3

8. Narsing Rao MP, Xiao M, Li WJ (2017) Fungal and bacterial pigments: secondary metabolites with wide applications. Front Microbiol 8:1113. https://doi.org/10.3389/fmicb.2017.01113

9. Pore TS, Khanolkar AB, Nadaf NH (2016) Production, purification, identification of prodigiosin from Serratia $\mathrm{sp}$ and its antimicrobial activity. Res J Life Sci Bioinform Pharm Chem Sci 1:1-12. https://doi.org/10.26479/2016.0106.05

10. Afra S, Makhdoumi A, Matin MM, Feizy J (2017) A novel red pigment from marine Arthrobacter sp. G20 with specific anticancer activity. J Appl Microbiol 123:1228-1236. https://doi. org/10.1111/jam.13576

11. Abraham J, Chauhan R (2018) Profiling of red pigment produced by Streptomyces sp. JAR6 and its bioactivity. 3 Biotech 8:22. https ://doi.org/10.1007/s13205-017-1044-7

12. Srinivasan M, Keziah SM, Hemalatha M, Devi CS (2017) Pigment from Streptomyces bellus MSA1 isolated from marine sediments. IOP Conf Ser Mater Sci Eng 263:022049. https://doi. org/10.1088/1757-899X/263/2/022049

13. Silva TR, Canela-Garayoa R, Eras J, Rodrigues MV, dos Santos FN, Eberlin MN, Neri-Numa IA, Pastore GM, Tavares RS, Debonsi HM, Cordeiro LR (2018) Pigments in an iridescent bacterium, Cellulophaga fucicola, isolated from Antarctica. Antonie van
Leeuwenhoek 112:479-490. https://doi.org/10.1007/s1048 2-018-1179-5

14. Ren Y, Gong J, Fu R, Zhang J, Fang K, Liu X (2018) Antibacterial dyeing of silk with prodigiosins suspention produced by liquid fermentation. J Clean Prod 201:648-656. https://doi. org/10.1016/j.jclepro.2018.08.098

15. Krishna PS, Sudha S, Reddy KA, Al-Dhabaan FA, Prakasham RS Charya MS (2017) Studies on wound healing potential of red pigment isolated from marine bacterium Vibrio sp. Saudi J Biol Sci 26:723-729. https://doi.org/10.1016/j.sjbs.2017.11.035

16. DeBritto S, Gajbar TD, Satapute P, Sundaram L, Lakshmikantha RY, Jogaiah S, Ito SI (2020) Isolation and characterization of nutrient dependent pyocyanin from Pseudomonas aeruginosa and its dye and agrochemical properties. Sci Rep 10:1-12. https ://doi.org/10.1038/s41598-020-58335-6

17. Kanelli M, Mandic M, Kalakona M, Vasilakos S, Kekos D, NikodinovicRunic J, Topakas E (2018) Microbial production of violacein and process optimization for dyeing polyamide fabrics with acquired antimicrobial properties. Front Microbiol 9:1495. https://doi.org/10.3389/fmicb.2018.01495

18. Ren Y, Gong J, Fu R, Li Z, Li Q, Zhang J, Yu Z, Cheng X (2017) Dyeing and antibacterial properties of cotton dyed with prodigiosins nanomicelles produced by microbial fermentation. Dyes Pigments 138:147-153. https://doi.org/10.3390/polym9100468

19. Behera T, Swain P, Mohapatra D (2013) Virulence determination of bacterial isolates through culture in India ink including broth. J Microbiol Antimicrob 5:87-90. https://doi.org/10.5897/JMA12 .010

20. Poddar K, Sarkar D, Sarkar A (2019) Construction of potential bacterial consortia for efficient hydrocarbon degradation. Int Biodeterior Biodegrad 144:104770. https://doi.org/10.1016/j. ibiod.2019.104770

21. Sarkar D, Prajapati S, Poddar K, Sarkar A (2019) Production of ethanol by Enterobacter sp. EtK3 during fruit waste biotransformation. Int Biodeterior Biodegrad 145:104795. https://doi. org/10.1016/j.ibiod.2019.104795

22. Kaur N, Seuylemezian A, Patil PP, Patil P, Krishnamurti S, Varelas J, Smith DJ, Mayilraj S, Vaishampayan P (2018) Paenibacillus xerothermodurans sp. nov., an extremely dry heat resistant spore forming bacterium isolated from the soil of Cape Canaveral, Florida. Int J Syst Evol Microbiol 68:3190-3196. https://doi. org/10.1099/ijsem.0.002967

23. Jain $A$, Jain $R$, Jain $S$ (2020) Motility testing: hanging drop method and stab. In: Jain A, Jain R, Jain S (eds) Basic techniques in biochemistry, microbiology and molecular biology, 1st edn. Springer, New York, pp 121-122

24. Zhang C, Brown PJ, Miles RJ, White TA, Grant DG, Stalla D, Hu Z (2019) Inhibition of regrowth of planktonic and biofilm bacteria after peracetic acid disinfection. Water Res 149:640-649. https ://doi.org/10.1016/j.watres.2018.10.062

25. Alekish M, Ismail ZB, Albiss B, Nawasrah S (2018) In vitro antibacterial effects of zinc oxide nanoparticles on multiple drugresistant strains of Staphylococcus aureus and Escherichia coli: An alternative approach for antibacterial therapy of mastitis in sheep. Vet World 11:1428-1432. https://doi.org/10.14202/vetwo rld.2018.1428-1432

26. Samyuktha S, Mahajan SN (2016) Isolation and identification of pigment producing bacteria and characterization of extracted pigments. Int J Appl Res 2:657-664

27. Biswas R, Vivekanand V, Saha A, Ghosh A, Sarkar A (2019) Arsenite oxidation by a facultative chemolithotrophic Delftia spp. BAs29 for its potential application in groundwater arsenic bioremediation. Int Biodeterior Biodegrad 136:55-62. https:// doi.org/10.1016/j.ibiod.2018.10.006 
28. Sarkar D, Prajapati S, Poddar K, Sarkar A (2020) Ethanol production by Klebsiella sp. SWET4 using banana peel as feasible substrate. Biomass Convers Biorefin. https://doi.org/10.1007/s1339 9-020-00880-1

29. Bisht G, Srivastava S, Kulshreshtha R, Sourirajan A, Baulmer DJ, Dev K (2020) Applications of red pigments from psychrophilic Rhodonellum psychrophilum GL8 in health, food and antimicrobial finishes on textiles. Process Biochem 94:15-29. https://doi. org/10.1016/j.procbio.2020.03.021

30. Parmar RS, Singh C (2018) A comprehensive study of ecofriendly natural pigment and its applications. Biochem Biophys Rep 13:22-26. https://doi.org/10.1016/j.bbrep.2017.11.002

31. Gupta N, Poddar K, Sarkar D, Kumari N, Padhan B, Sarkar A (2019) Fruit waste management by pigment production and utilization of residual as bioadsorbent. J Environ Manage 244:138-143. https://doi.org/10.1016/j.jenvman.2019.05.055

32. Sarkar D, Gupta K, Poddar K, Biswas R, Sarkar A (2019) Direct conversion of fruit waste to ethanol using marine bacterial strain Citrobacter sp. E4. Process Saf Environ Prot 128:203-210. https ://doi.org/10.1016/j.psep.2019.05.051

33. Saleh SS, Glick BR (2001) Involvement of gacS and rpoS in enhancement of the plant growth-promoting capabilities of Enterobacter cloacae CAL2 and UW4. Can J Microbiol 47:698705. https://doi.org/10.1139/w01-072

34. Haddix PL, Shanks RM (2018) Prodigiosin pigment of Serratia marcescens is associated with increased biomass production. Arch Microbiol 200:989-999. https://doi.org/10.1007/s0020 3-018-1508-0

35. Anwar MM, Shalaby M, Embaby AM, Saeed H, Agwa MM, Hussein A (2020) Prodigiosin/PU-H71 as a novel potential combined therapy for triple negative breast cancer (TNBC): preclinical insights. Sci Rep 10:1-15. https://doi.org/10.1038/s41598-02071157-w

36. Danevčič T, Borić Vezjak M, Zorec M, Stopar D (2016) ProdigiosinA multifaceted Escherichia coli antimicrobial agent. PLoS One 11:0162412. https://doi.org/10.1371/journal.pone.0162412

37. Sibero MT, Bachtiarini TU, Trianto A, Lupita AH, Sari DP, Igarashi Y, Harunari E, Sharma AR, Radjasa OK, Sabdono A (2019) Characterization of a yellow pigmented coral-associated bacterium exhibiting anti-bacterial activity against multidrug resistant (MDR) organism. Egypt J Aquat Res 45:81-87. https://doi. org/10.1016/j.ejar.2018.11.007

38. Choi SY, Kim S, Lyuck S, Kim SB, Mitchell RJ (2015) High-level production of violacein by the newly isolated Duganella violaceinigra str. NI28 and its impact on Staphylococcus aureus. Sci Rep. https://doi.org/10.1038/srep15598

39. Rettori D, Durán N (1998) Production, extraction and purification of violacein: an antibiotic pigment produced by Chromobacterium violaceum. World J Microb Biot 14:685-688. https://doi. org/10.1023/A:1008809504504

40. Khanam B, Chandra R (2018) Comparative analysis of prodigiosin isolated from endophyte Serratia marcescens. Lett Appl Microbiol 66:194-201. https://doi.org/10.1111/lam.12840

Publisher's Note Springer Nature remains neutral with regard to jurisdictional claims in published maps and institutional affiliations. 